\title{
SAJÁTOS NEVELÉSI IGÉNYŰ HALLGATÓK KÉPZÉSE AZ SZTE MÉRNÖKI KARÁN
}

\author{
Gál József - Panyor Ágota - Farkas Ferenc
}

Munkánk során az vezényeljen bennünket, hogy ,a legcsekélyebb ember is teljes lehet, teljes annyiban, amennyiben eljut saját lehetőségeinek csúcsára.” (Goethe)

\begin{abstract}
Absztrakt: Az SZTE Mérnöki Karán első lépésként felmértük a speciális nevelési igényü hallgatókat, helyzetképet kaptunk, és megcéloztuk a lemorzsolódást csökkentő program beindítását. Jelen tanulmányban a 2017/2018. tanév 2. szemeszterének kezdetén, aktív hallgatók véleményét mértük fel, kiemelten foglalkozva a Kar leginkább nagy létszámú szakjaival (gépész- ill. élelmiszermérnök). Megállapítottuk, hogy fejlesztésre mindenképpen szükség van, hiszen ennek során az egyénhez igazított követelmények meghatározása evidens, emellett a kortárs csoportokba tartozók beilleszkedését elő kell segítenünk és sikerélményt kell biztosítani hallgatóinknak. Rávilágítottunk arra is, hogy szükséges annak feltárása, hogy milyen problémák állhatnak tanulmányi szempontból a tanulási nehézségek hátterében, úgymint diszlexia, diszgráfia, hallási vagy látási problémák, koncentráció zavar, stressz, vagy egyéb okok.
\end{abstract}

\begin{abstract}
At University of Szeged Faculty of Engineering we have studied students with special needs, we got a picture of the situation and we aimed at launching a drop-out program. In this paper at the beginning of 201/2018 academic year we surveyed active status students' opinions in spring semester, underlined the most large-scale professions (mechanical and food engineering). We have found that development is absolutely necessary since the definition of tailor-made requirements is evident in addition, we need to facilitate the integration of people in contemporary groups and we must provide our students with a sense of success. We also highlighted it, how to explore it, what problems can be faced in terms of learning in the context of learning difficulties, like dyslexia, dysgraphia, hearing or vision problems, concentration disturbance, stress, or other causes.
\end{abstract}

Kulcsszavak: tanulási nehézségek, lemorzsolódás, speciális nevelési igényü hallgatók

Keywords: learning difficulties, dropouts, students with special educational needs

\section{Bevezetés}

Az UNESCO (1994) ajánlása szerinti alapelv, hogy ,az iskolák minden gyermeket befogadjanak, függetlenül testi, értelmi, szociális, érzelmi, nyelvi vagy egyéb állapotuktól: beleértve a fogyatékos és a tehetséges gyermekeket és kiskorú foglalkoztatottakat, nomád körülmények között élő, a nyelvi, etnikai, vagy kulturális kisebbséghez tartozó gyermekeket és más hátrányos helyzetü, vagy peremterületen élö csoportok gyermekeit." (http://www.unesco.org/education/pdf/SALAMA_E. PDF, 2019.01.05.)

Az egyetemi oktatásba belépők közül azokat a hallgatóinkat érinti, akik a felvételi eljárás alapján aktív részeseivé váltak a Mérnöki Karon tanulóknak, de valamilyen vonatkozásban hátrányos helyzetünek minősülnek. Jelenleg az ilyen irányú nevelést igénylők aránya mindössze 3\%.

Az ajánlás azt tartalmazza, hogy ,az inkluzív nevelés olyan megközelítési mód, amely arra ad választ, hogyan lehet az oktatási rendszereket átalakítani annak érdekében, hogy kezelni tudják a tanulók közötti különbségeket. (https://unesdoc.unesco.org/ark:/48223/pf0000134785, 2019.01.05.) 
A Szegedi Tudományegyetem Mérnöki Karán első lépésként felmértük a speciális igényü hallgatókat, helyzetképet kaptunk, és megcéloztuk a lemorzsolódást csökkentő program beindítását. (Lendvai et al., 2018)

A tanulmányban a 2017/2018. tanév 2. szemeszterének kezdetén aktív hallgatók véleményét mértuik fel, kiemelten foglalkozva a Kar leginkább nagy létszámú szakjaival.

\section{A lemorzsolódás okai és a hátrányos helyzetü hallgatók nehézségei}

A lemorzsolódás ismert okai közül meghatározó az alapozó tárgyak nehezen teljesíthetősége. Az eddigi oktatási tapasztalataink alapján megerősíthetjük, amit a felmérés is figyelmünkbe ajánlott, hogy egyre nagyobb problémát jelent a koncentrálás, az elhangzottak értelmezése, illetve a számonkérés során a nyelvhelyesség használata.

E körbe tartozók között - föleg az írásbeli számonkérés során - nem tudják helyesen értelmezni a feltett vizsgakérdéseket illetve számos esetben értelmetlen mondatokat alkotnak. Igyekeztünk megismerni mind reál, mind humán tárgykör esetén a hallgatók hozzáállását az adott tantárgyhoz, illetve szerintük az egyes tantárgyak teljesítésének realitását. Nemcsak a hallgatói oldalról célszerü feltérképezni a helyzetet, mivel lehetséges, hogy néhány kurzus esetén a számonkérés módja is túl nehéz az adott szakon. Ez abból is adódhat, hogy különböző társadalmi helyzetböl, illetve eltérő minőségi színvonalú középfokú oktatásból származnak a hallgatók. Azt tapasztaljuk, hogy a középiskolák megítélése, érdekeltsége abban van, hogy végzett tanulóik minél nagyobb arányban kerüljenek be valamilyen felsőfokú képzésbe. Gyakori, hogy a középiskolák jelentősen felülértékelik diákjaik tudását. Ez valószínüleg egyfajta tévesen megfogalmazott szemléletből adódódik, vagy sajnálatból, a speciális igényü hallgatók esetében ez még inkább jellemzőbb. Fontos szerepe lehet olyan tényezőknek is, mint a külön tanárok, felkészítő órák, családtagok iskolázottsága, melyek mind befolyásolják egy-egy tantárgy sikeresebb teljesítését.

Emellett szükséges továbbgondolni és felmérni, hogy a hallgatóinknak melyek a föbb problémáik, milyen nehézségekkel szembesülnek adott tantárgyak esetében.

Például:

- túl sok az anyag,

- nem érti az órán elhangzottakat,

- számára nem dolgozható fel a tananyag, nem tudja, hogyan kell értelmezve, hatékonyan tanulni,

- magas a követelmény,

- az oktató-hallgató viszony,

- nem tanult eleget,

- elhanyagolta a tanulást.

Fontos a hallgatók szemszögéből azt is vizsgálni, hogy miben láthatják a tanulási problémáikra a megoldást, hogyan tudjuk őket segíteni a lemaradás elkerülésében.

Először is fontos lenne, hogy a hallgató el akarja végezni a képzést, ennek érdekében hajlandó legyen - legalább - a minimális együttmüködésre (pl. CooSpace 
üzenetek elolvasása, értelmezése, a határidők betartása stb.). Nem ritka, hogy a szülő jobban szeretné a diplomát, mint a fiatal, akinek fogalma sincs arról, hogy mit is csinál, mi a különbség, ha lesz diplomája, vagy ha nem. Az is előfordul, hogy a szülő - egyfajta túlzott szeretettől vezérelve - túlzott mértékben megértő és nem állít gyermeke elé elvárást, követelményt. A hibákat az oktatókban, az oktatási rendszerben látja, azzal nem foglalkozva, hogy a hallgató megtesz-e minden tőle telhetöt a sikeres teljesítés érdekében.

Az oktatók segítsége csak a hallgatóval történő együttmüködéssel lehet eredményes, ehhez az alábbiak szükségesek:

- a kurzus látogatása,

- odafigyelés az órákon,

- extra segédanyag összeállítása,

- oktató többféleképpen magyarázzon,

- összefoglalások adott témakör után,

- részletesebb, gyakorlatiasabb jegyzet,

- jobb hallgató-oktató viszony,

- szemléletesebb előadások,

- több tanulásra fordított idő, vagy

- egyáltalán nincs probléma, csak a hallgató vallja be, hogy nem fordít elég időt a tanulásra, nem érdekli stb.

Az elmúlt években már jellemző, hogy egyfajta „kiskapu” alternatívaként a szülö és a hallgató együtt törekszik arra, hogy találjon valamilyen problémát, és arról hivatalos dokumentumot is szerezzen. Ebben az esetben elveszik a realitásérzék, pl. diszkalkulia igazolására törekszik - már nem is érettségizett matematikából - de mérnök szeretne lenni, ahol alapvetőek a matematikai ismeretek. Nem foglalkoznak a későbbi munkaerő-piaci értékével, így determinálják és stabilizálják a hallgató számára a folyamatos kudarcot.

A lemorzsolódás csökkentése érdekében célszerü új módszereket kifejleszteni, amellyel ösztönözni lehet a hallgatókat a tanulásra. Az új módszertanok pedagógiai szempontból is új kihívásokat jelenthetnek adott esetben, amelyre az oktatóknak is fel kell készülni.

Hangsúlyoznunk kell, hogy segíteni csak azokon tudunk, akik elfogadják a felajánlott lehetőségeket, akik el akarják végezni az egyetemi tanulmányaikat.

Föleg olyanoknál, akiknek:

- családi háttér/vállalkozás miatt kötelező elvégezni a szakot,

- nem tudja még, mivel szeretne foglalkozni,

- csak azért jár egyetemre, hogy ne kelljen még dolgoznia.

Ez esetben megmutatjuk hallgatóinknak, hogy adott végzettséggel milyen munkakörben tudnak elhelyezkedni. Kiemeljük nekik a jövőbeni tanulmányaik érdekességeit, és azokat a plusz egyedi lehetőségeket, amelyekkel sikeresebben tudják a tanulmányaikat teljesíteni. Azok számára, akik pályát tévesztettek, felajánlunk olyan tanulási lehetőségeket, ahol nem a matematika, kémia, fizika a determináló, ahol még lehet sikerélményük. 
Jelen tanulmányunkban kiemelten a müszaki képzési területhez tartozó Gépészmérnök szakos és az agrár képzési területhez tartozó Élelmiszermérnök szakos elsőéves hallgatók megkeresése volt a leginkább releváns (a legjelentősebb a képzésben résztvevők létszáma), hiszen a problémák mögött a fenti (alapozó) tantárgyak nehezen teljesíthetősége jelentkezik.

A lemorzsolódás okait vizsgálva a tanulmányi (tanulási) problémák mögött további fontos tényezők is megjelennek:

- szociális háttér (család, barátok, tanulók közötti viszony, kényszer, oktatási intézmény légköre),

- gazdasági helyzet (önköltséges képzésre való átsorolásból adódó pénzügyi nehézségek, tanulmányok melletti munkavégzés az önfenntartás/részbeni családi finanszírozás miatt),

- jövőkép hiánya,

- egészségi állapot.

\section{Tanulási problémák hátterének elemzése}

A tanulás olyan akarati megnyilvánulás, amely erőfeszítést kíván. Az oktatóknak/tanároknak a tanulás kifejezés mögött az ismeretbővítés, hatékony tanítás-tanulás szavak jutottak eszükbe. Mindez a hallgatók esetében sokkal összetettebb módon jelentkezik. Az EFOP-3.4.3-16-00014 projekt keretében az AP1-IE-8(AP1_MK) a „Speciális igényü hallgatók felmérése a Mérnöki Karon” tanulmány az alábbi eredményeket hozta.

A felmérésben részt vett Gépészmérnök szakos hallgatók a tanulás kifejezésre az 1. ábrán látható szófelhőben megjelenő tartalmakat gondolják. A felhőben található szavak közül a piros színủ szavak pozitív tartalmúak, míg a sötétkékek kimondottan negatív érzelmi töltetüek. Világos kékkel lettek jelölve azok a szavak, melyek érzelmileg semlegesek. A szavak mérete pedig arányos az előfordulásuk mértékével. A kapott válaszok alapján megállapíthatjuk, hogy a Gépészmérnök szakos hallgatók között leginkább pozitív töltetű szavak jutnak a hallgatók eszébe a tanulásról. Legtöbben a tudás szóval vontak párhuzamot, amit a pozitív szavak közé soroltunk. A következőek az értelmezés, a megértés, az információ és az ismeret voltak. Hat negatív hangzású szó jelent csak meg a válaszokban a tanulással kapcsolatban, ezek közül a szenvedés emelkedett ki a többi közül. Összességében levonható az a következtetés az esetükben, hogy a tanulás, mint szó többükben pozitív érzelmet vált ki (Lendvai et al., 2018; Gál et al., 2019). 


\section{1. ábra: A megkérdezett Gépészmérnök szakos hallgatók asszociációi a tanulás szóra}

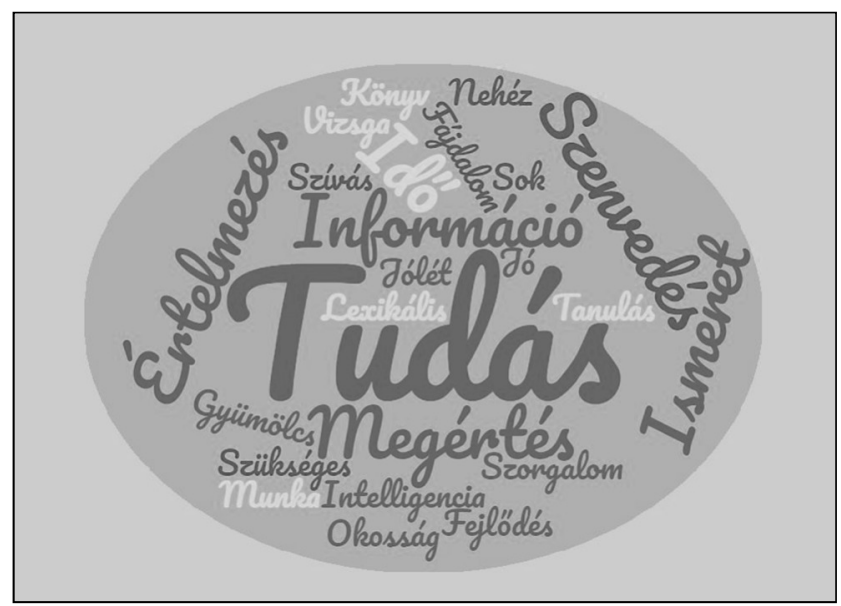

Forrás: Lendvai et al., 2018

Az Élelmiszermérnök hallgatók esetében megjelenő tanulás szóra történő asszociációkat a 2. ábrán látható szófelhő szemlélteti azonos megfeleltetési módon. Az ábra alapján megállapíthatjuk, hogy az Élelmiszermérnök szakos hallgatók esetén nem lehet egyértelmüen meghatározni, hogy kik vannak többségben, azok, akikből a tanulás pozitív, kellemes érzést vált ki vagy azok, akikből negatívat. A pozitív töltetü tudás hasonló számú hallgatónak jutott eszébe, mint a negatív jelentésü stressz. A tanulás, mint szó többükben inkább negatív érzelmet vált ki: 9 féle pozitív jelentésủ szó került a kérdőíveikre, míg 15 negatív asszociáció. Ez azt sugallja, hogy valami oknál fogva ezen hallgatók többségében a tanulás negatív, rossz érzéssel párosul. (Lendvai et al., 2018; Gál et al., 2019)

\section{2. ábra A megkérdezett Élelmiszermérnök szakos hallgatók asszociációi a tanulás szóra}

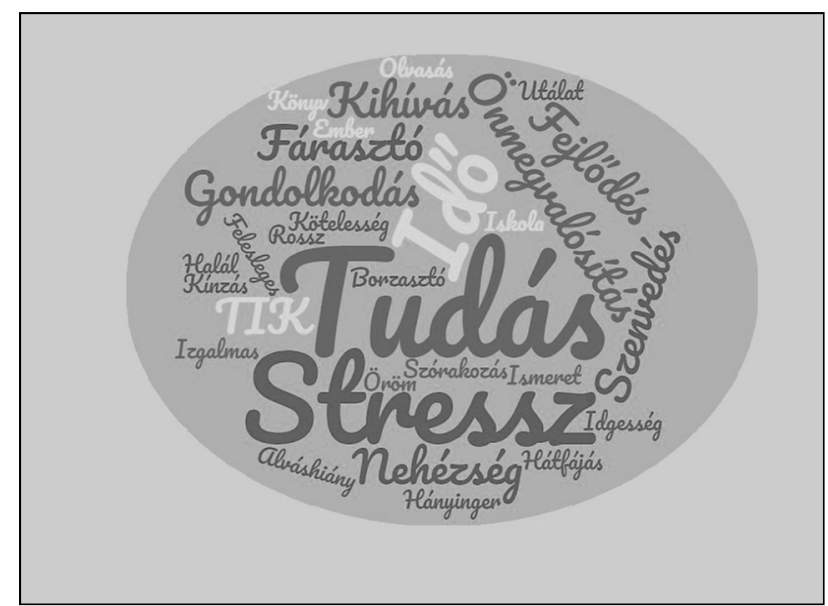

Forrás: Lendvai et al., 2018 
Feltételezésünk szerint nagyon kevesen vannak, akik folyamatosan és rendszeresen óráról-órára tanulnak. Így túlzottan nagy mennyiségü az a tananyag, amelyet nagyon rövid idő alatt kell elsajátítaniuk és ez számos felkészülési problémához vezet. A hivatkozott felmérés ezen kérdése kapcsán a hallgatók az általuk leginkább igaznak gondolt válaszokat jelölték meg. A Gépészmérnök szakos hallgatók által megjelölt válaszokat a 3. ábra szemlélteti. A diagramról leolvasható, hogy a hallgatók fele a jellemzően csak $\mathrm{ZH} /$ vizsga előtti tanulásra specializálódott, ugyanakkor 1/3 részük inkább a folyamatosan, de néhány tárgyból csak a ZH/vizsga elöttre voksolt. Sajnos a napról-napra történő tanulás egyáltalán nem jellemző, csupán 1 hallgató érzi ezt a leghatékonyabb eljárásnak. (Lendvai et al., 2018; Gál et al., 2019)

\section{3.ábra: A megkérdezett Gépészmérnök hallgatók megoszlása a tanulási módszerük alapján (\%)}

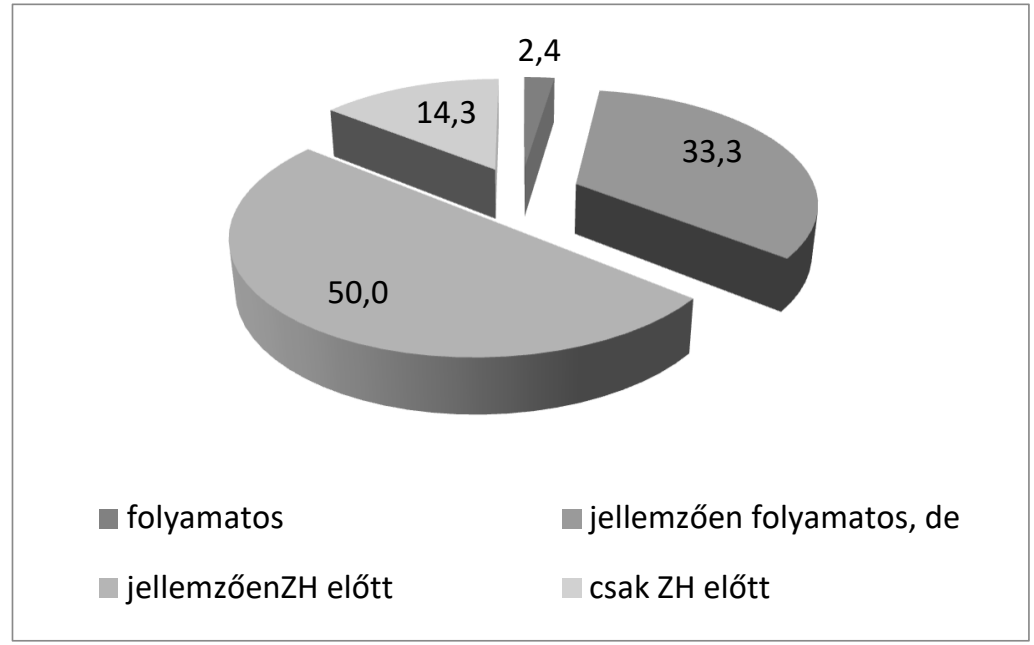

Forrás: a Mérnöki Kar oktatóinak felmérése alapján (2017/2018)

Ezen tárgykörben az Élelmiszermérnök szakos hallgatók tanulással kapcsolatos módszereire kapott válaszokat a 4. ábra szemlélteti. A diagram jól összefoglalja azt, hogy a hallgatók kicsivel több mint fele (54\%) a jellemzően csak a ZH/ vizsga elötti tanulásra specializálódott, ugyanakkor $24 \%$-uk inkább a folyamatosan, de néhány tárgyból csak a ZH/vizsga előtt-re voksolt. Sajnos a napról-napra történő tanulás szinte egyáltalán nem jellemző, csupán 2 hallgató érzi ezt a leghatékonyabb eljárásnak. A megkérdezettek $18 \%$-a pedig bevallja, hogy csak a ZH-ra, vizsgára készül. Tehát a tanulással kapcsolatos módszerek változtatása is szükséges lehet, amelyre a figyelmet fel kell hívni. Ezt a célt szolgálhatják az oktatói mentorálási programhoz kapcsolódó támogató elemek minél teljesebb körü alkalmazása is.

A napi készülés mennyiséget kellett megjelölni a szorgalmi, illetve a vizsgaidőszakban, attól függően, hogy lesz-e ZH vagy sem. A Gépészmérnök szakos hallgatók által megjelölt értékeket mutatja az 1. táblázat adatai. A vastagon kiemelt számok a legjellemzőbb tanulási intervallumokra utalnak. Az előző kérdésre adott válaszokkal egybecsengenek a mostaniak, vagyis a hallgatók jellemzően 
kampányszerüen készülnek, a szorgalmi időszakban sokan gyakorlatilag semmit, bár figyelemre méltónak tekinthető az a 3 fö, aki ekkor is minimum 3 órát foglalkozik a tananyaggal naponta. A vizsgaidőszakban pedig kiemelkedő azok aránya (kb. 1/3), akik vállaltan minimum 9 órát töltenek a tanulással. (Lendvai et al., 2018; Gál et al., 2019)

\section{4. ábra: A megkérdezett Élelmiszermérnök szakos hallgatók megoszlása a tanulási módszerük alapján}

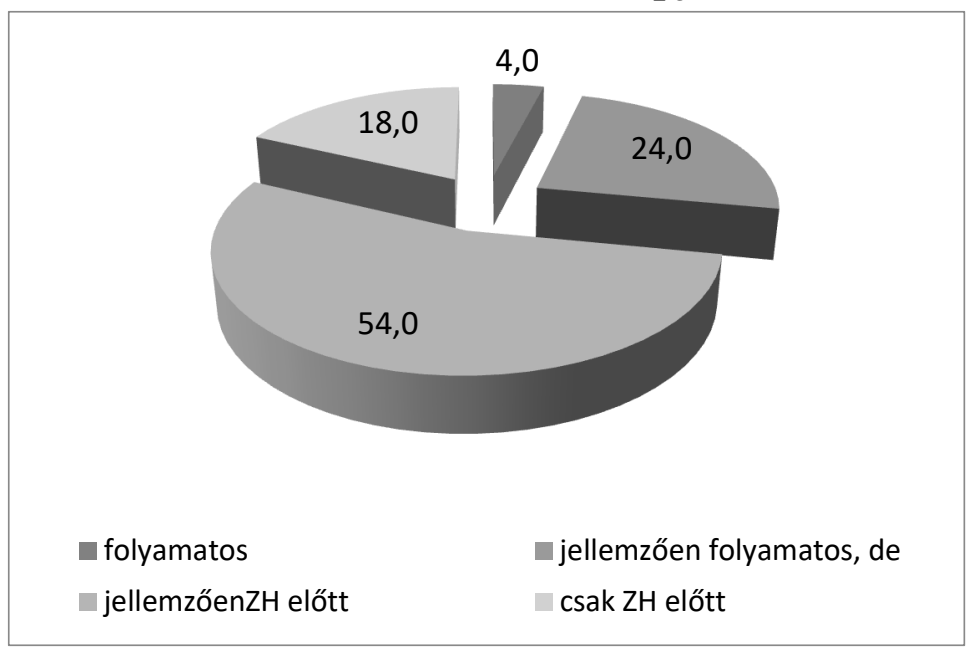

Forrás: a Mérnöki Kar oktatóinak felmérése alapján (2017/2018)

A hivatkozott felmérés további részében felmérésre került az is, hogy a hallgatók mennyi időt fordítanak tanulásra.

1. táblázat: A megkérdezett Gépészmérnök szakos hallgatók megoszlása a tanulásra fordított idő alapján (\%)

\begin{tabular}{|l|r|r|r|r|r|r|}
\hline & $\begin{array}{r}0-1 \\
\text { óra/ } \\
\text { nap }\end{array}$ & $\begin{array}{r}1-3 \\
\text { ora/ } \\
\text { nap }\end{array}$ & $\begin{array}{r}3-6 \\
\text { óra/ } \\
\text { nap }\end{array}$ & $\begin{array}{r}6-9 \text { óra/ } \\
\text { nap }\end{array}$ & $\begin{array}{r}9-12 \\
\text { óra/ } \\
\text { nap }\end{array}$ & $\begin{array}{r}12 \\
\text { oránál } \\
\text { több/ } \\
\text { nap }\end{array}$ \\
\hline $\begin{array}{l}\text { szorgalmi időszak, ZH } \\
\text { nélkül }\end{array}$ & $\mathbf{6 9 , 0}$ & 23,8 & 7,1 & - & - & - \\
\hline $\begin{array}{l}\text { szorgalmi időszak ZH } \\
\text { esetében }\end{array}$ & 9,5 & $\mathbf{4 2 , 9}$ & 35,8 & 11,9 & - & - \\
\hline $\begin{array}{l}\text { vizsgaidőszak, könnyebb } \\
\text { tárgy esetében }\end{array}$ & 11,9 & $\mathbf{3 8 , 1}$ & 35,7 & 14,3 & - & - \\
\hline $\begin{array}{l}\text { vizsgaidőszak, nehezebb } \\
\text { tárgy esetében }\end{array}$ & - & 11,9 & 19,0 & $\mathbf{3 3 , 3}$ & 26,2 & 9,5 \\
\hline
\end{tabular}

Forrás: a Mérnöki Kar oktatóinak felmérése alapján (2017/2018)

Az Élelmiszermérnök szakos hallgatók esetében a tanulásra fordított idő tekintetében a napi készülés mennyiségét a szorgalmi, illetve a vizsgaidőszakban - 
attól függően, hogy lesz-e ZH/vizsga vagy sem - a 2. táblázat foglalja össze. A vastagon kiemelt számok a legjellemzőbb tanulási intervallumokra utalnak. Láthatjuk, hogy a szorgalmi időszakban a hallgatók kicsivel több, mint fele kampányszerüen készül, elő sem veszi a jegyzeteket, míg kb. 1/3-uk a szorgalmi időszakban is minimum 1 órát foglalkozik a tananyaggal naponta. 7 hallgató pedig úgy nyilatkozott, hogy napi 3 órát vagy annál is többet készül. A vizsgaidőszakban természetesen nő az egyre többet tanulók aránya. Ez azonban már sok esetben csak a kampányszerü, felületesebb tudást jelenti, sőt számos esetben az alapok kellő mélységü ismerete nélkül sok esetben kudarchoz vezetnek a vizsgák. Az elért eredmények egyáltalán nem tükrözik a ráfordított tanulási időt, melynek egy része akár csak „bemagolást” jelent és mivel nem értik a tanultakat, nem is képesek megfelelő eredményt produkálni. (Lendvai et al., 2018; Gál et al., 2019)

\section{2. táblázat: A megkérdezett Élelmiszermérnök szakos hallgatók megoszlása a tanulásra fordított idő alapján (\%)}

\begin{tabular}{|l|r|r|r|r|r|r|}
\hline & $\begin{array}{r}0-1 \\
\text { óra/ } \\
\text { nap }\end{array}$ & $\begin{array}{r}1-3 \\
\text { ora/ } \\
\text { nap }\end{array}$ & $\begin{array}{r}3-6 \\
\text { óra/ } \\
\text { nap }\end{array}$ & $\begin{array}{r}6-9 \\
\text { óra/ } \\
\text { nap }\end{array}$ & $\begin{array}{r}9-12 \\
\text { óra/ } \\
\text { nap }\end{array}$ & $\begin{array}{r}12 \text { óránál } \\
\text { több/ nap }\end{array}$ \\
\hline $\begin{array}{l}\text { szorgalmi időszak, ZH } \\
\text { nélkül }\end{array}$ & $\mathbf{5 6 , 0}$ & 30,0 & 12,2 & 2,0 & - & - \\
\hline $\begin{array}{l}\text { szorgalmi időszak ZH } \\
\text { esetében }\end{array}$ & 6,0 & $\mathbf{3 4 , 0}$ & $\mathbf{3 2 , 0}$ & 24,0 & 4,0 & - \\
\hline $\begin{array}{l}\text { vizsgaidőszak, } \\
\text { könnyebben teljesíthető } \\
\text { tárgy esetében }\end{array}$ & 8,0 & $\mathbf{4 0 , 0}$ & 34,0 & 14,0 & 4,0 & - \\
\hline $\begin{array}{l}\text { vizsgaidőszak, } \\
\text { nehezebben teljesíthető } \\
\text { tárgy esetében }\end{array}$ & 8,0 & 24,0 & $\mathbf{3 4 , 0}$ & 26,0 & 8,0 & \\
\hline
\end{tabular}

Forrás: a Mérnöki Kar oktatóinak felmérése alapján (2017/2018)

Amennyiben a lemorzsolódás hátterében nem állnak fenn egészségügyi, vagy gazdasági, vagy tanulási problémák, akkor jelentős mértékben képesek ösztönzőleg is hatni az egyes hallgatókra a társaik tanulási akarata és képessége. Ezért a jelzett tanulmány arra is kitért, hogy a megkérdezettek hogyan helyezik el a tanulásukat a többi hallgatóhoz képest (többet, kevesebbet vagy ugyanannyit tanulnak).

A gépészmérnökök esetében csupán 1 fö gondolja úgy, hogy sokkal többet tanul a többieknél, további $43 \%$ érzi azt, hogy többet tanul, mint a társai. Ugyanakkor a válaszadók megközelítőleg fele (54\%) jelölte meg azt a válaszlehetőséget, hogy kevesebbet. A kapott adatokat az 5. ábra szemlélteti. 


\section{5. ábra: A megkérdezett gépészmérnök hallgatók megoszlása a társaikhoz képesti tanulás mennyiségének megítélése alapján (\%)}

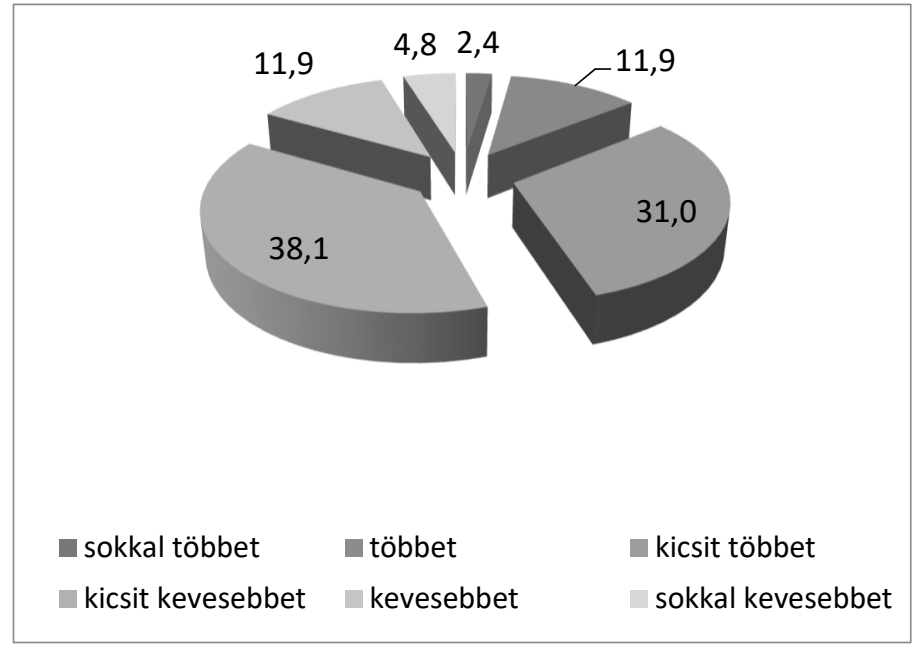

Forrás: a Mérnöki Kar oktatóinak felmérése alapján (2017/2018)

Az élelmiszermérnökök esetében a csoporttársakhoz viszonyítva csupán 2 fö gondolja úgy, hogy sokkal többet tanul a többieknél, és további 52\% érzi azt, hogy többet tanul, mint a társai. Ugyanakkor $44 \%$ nyilatkozott úgy, hogy szerinte kevesebbet tanul (6. ábra).

6. ábra: A megkérdezett élelmiszermérnök hallgatók megoszlása a társaikhoz képesti tanulás mennyiségének megítélése alapján (\%)

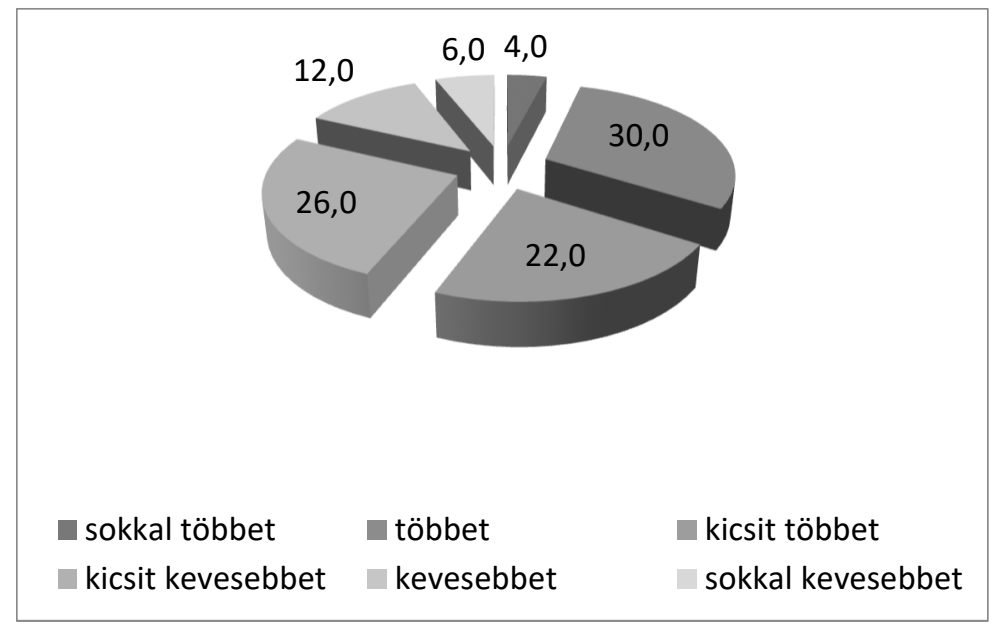

Forrás: a Mérnöki Kar oktatóinak felmérése alapján (2017/2018)

Amennyiben van rá mód, szükséges feltárni, hogy milyen problémák állhatnak tanulmányi szempontból a tanulási nehézségek hátterében, úgymint diszlexia, diszgráfia, hallási vagy látási problémák, koncentráció zavar, stressz vagy egyebek. A felmérésben résztvevők közül csak néhányan voltak, akik diszlexiás, diszgráfiás, illetve hallással kapcsolatos problémával küszködnek. 


\section{A hallgatók fejlesztésének lehetőségei}

A fejlesztés mindenképpen szükséges, hiszen a fejlesztések során az egyénhez igazított követelmények meghatározása evidens, emellett a fejlesztésre szorulókat a kortárs csoportokba tartozók beilleszkedését elösegítenünk, sikerélményt biztosítani kell hallgatóinknak.

A sajátos képzést igénylő hallgatóinknak további lehetőségeket szükséges felajánlani, meg kell őket szólítani, érdeklődésüket felkelteni. Abból induljunk ki, hogy ,amit elmondok, azt elfelejtem, amit látok azt megfigyelem, amit csinálok, azt megtanulom" - hangzik a közmondás. Ebben vannak segítségünkre az alábbi oktatási formák:

- Nagyon fontos a sokoldalú szemléltetés, cselekedtetés. Jól tudjuk, hogy azt tudja igazán a hallgató elsajátítani, amit testi mozgás közben dolgoz fel.

- A jó iskola az élményt ad; ezzel mi is igyekszünk Karunkon élni az oktatás során, és ezzel valamilyen fokon örömet szerezni hallgatóinknak, de legalábbis erőt adni a felkészüléshez.

- Ahol csak mód van rá nem a szorongást, hanem az érdeklődést próbáljuk felkelteni a legkülönbözőbb cselekedetekkel, cselekvésben elérhető sikerekben segítségükbe lenni.

- A valamilyen formában hátrányos helyzetü hallgatók az átlagosnál érzékenyebbek is. Fokozottan vigyáznunk kell, hogy az ő esetükben a lassúbb fejlődés is eredmény. Kedvét szegi, ha a tehetetlenség tudatát tápláljuk belé.

- Jellemző rájuk, hogy egyesek túl gyorsan és korán akarnak eredményt elérni és gyakran így válik munkájuk eredménytelenné. Ilyen esetekben a negatív visszajelzés helyett pozitív visszajelzést állítjuk stratégiánk középpontjába. Saját életútjukon próbáljuk fejleszteni fejlesztő együttélésben őket, a kívánt eredményekhez eljuttatni.

- Azt tapasztaljuk, hogy a személyes törődés később biztatássá fordulhat. Esetükben kevés eredménynek is örülni kell.

Mindezt érdemes a Mérnöki Karon tanított szakterületekre értelmezni, hiszen a gyakorlati képzés fontossága egyre növekszik, viszont elméleti megalapozottság nélkül nem valósítható meg. Egyre jelentősebb társadalmi igényként jelenik meg, hogy a kész ismeretek átadása helyett a megismerés eszközeit kell elérhetővé tenni lehetőleg mindenki számra. Vagyis az oktatást termelés közelbe kell vinni, életszerübbé kell tenni. E cél megvalósítása kapcsán kiemelt hangsúlyt kapnak az üzemlátogatások, a kirándulások, a termékbemutatók, a mérnöki képzéshez szorosan kapcsolható vállalatlátogatások. Tovább szélesíti a lehetőségeket a duális és kooperatív képzésben megjelenő gyakorlati ismeretek széleskörü vállalati kapcsolatrendszeren keresztüli bővítése.

Összegezve, egyre nagyobb jelentőségre tesz szert az elméleti tudásanyag minél szélesebb körének gyakorlatba való átültetése. Erre komoly anyagi forrásokat is szükséges megteremteni és tovább kell bővíteni a forrásbevonás lehetőségeit a gyakorlatias képzések vonatkozásában. 


\section{A hallgató, az oktató és az intézmény együttmúködésétől elvárható eredmények}

Mivel a legcsekélyebb ember is lehet teljes, amennyiben eljut saját lehetőségének csúcsára - fogalmaztuk meg korábban - éppen ezért türelemmel kell lennünk azoknál a hallgatóknál, akik lassabban fejlődnek az átlagnál, vagy az érdeklődési körük fellobbanását nehezebb kivárni, bízva abban, hogy a befektetett energiánk előbbutóbb kamatozni fog.

Ellentmondást érzünk abban a tekintetben is, hogy egyre több helyen megfogalmazzák azt a társadalmi igényt, hogy mit kíván a termelés (a gyakorlat) az oktatástól? Egyértelmủ, hogy az igény a gyakorlatiasabb képzést szorgalmazza, a használható ismeretek elsajátítását kéri. Ezzel szemben az erre fordítható összeg azt megközelítőleg sem biztosítja.

Sok hallgató van, akik nem ismerik az egyetemi élet tanulási szokásait. Az él a tudatukban, hogy csak kollokviumokból, beszámolókból és zárthelyi dolgozatokból áll az egyetemi tanulmány. Úgy ítélik meg, hogy közben elhagyható a folyamatos tanulás. Ismert, hogy az olyan tantárgyak esetében, mint a matematika, kémia, fizika, biológia - az elsődleges a bevésés, rögzítés, így nélkülözhetetlen, elmaradhatatlan kell, hogy legyen az óra utáni gyakorlás, a tanultak áttekintése. Az egyes szakokon, mint például az Élelmiszermérnöki szakon a biológia, a kémia; a Gépészmérnöki szakon a matematika és a fizika a legnehezebb tárgyak. Az oktatásban résztvevőknek pedig szükséges feleleveníteni, illetve pótolni a korszerü pedagógiai ismereteket.

Arról meg vagyunk győződve, hogy a jövő a tehetségeké, a tanultaké, a kitartó, szívós, terhelést jól bíróké lesz. „A tehetség fejlesztésében lényeges az energiákat jól felhasználni; hasznos feladatokra terelni a figyelmeket." (Csíkszentmihályi, 2010) Tehát a feladatunk kettős. Egyfelől úgy kell kezelnünk a hallgatóinkat, hogy mindenki tehetséges, még akkor is, ha teljesítőképesség szempontjából nagyon különbözőek. Másfelől tudatosítani kell hallgatóinkban azt is, hogy a felzárkóztatás nélkülünk, az oktatók aktív részvétele nélkül eredménytelen törekvés.

Tapasztaljuk azonban azt is, hogy nem mindenki igényli a segítségünket. Ezekben a hallgatókban fel kell keltenünk a tanulási igényt, ez pedig összehasonlíthatatlanul nehezebb feladat, mint az egyszerü tanulmányi segítés. Törekednünk kell arra, hogy a lemorzsolódás minél kevesebb legyen a Mérnöki Karon.

Mi arra teszünk kísérletet tanulmányunkban, hogy megfogalmazzuk a Mérnöki Kar sajátos szerepét a különböző képességü hallgatóink felzárkóztatása érdekében. A képességfejlesztés és tehetséggondozás egymástól elválaszthatatlan. Ennek fontos tényezöi: az adottság, rátermettség, hajlam, képesség, tehetség, intelligencia, kreativitás. A velünk született adottságok csak lehetőséget jelentenek a képességek pozitív, vagy negatív irányú kifejlődéséhez. A lehetőség még nem valóság, valósággá csak tanulás, gyakorlás útján válik. A kreatív személyiséget a könnyedség, a mozgékonyság, a kidolgozottság, a problémák iránti érzékenység, a problémák újra fogalmazása jellemzi. Az alkotó emberek jobb megfigyelők; azt is látják, amit mások látnak, de azt is, amit mások nem látnak. Hajlamosabbak arra, hogy megbirkózzanak a nehézségekkel, minthogy tehetetlenné váljanak azokkal szemben. Ilyen 
megnyilvánulások tapasztalhatók hallgatóink jelentős részénél. Az alkotó személy kíváncsi, vállalkozó szellemü, kezdeményezőkészséget mutat. Uralni akarja a problémát. Ezek a hallgatók kiemelkedő munkateljesítményt nyújtanak, csak menedzselni kell őket. A hallgatók másik részénél ez hiányzik, vagy csak részben müködik. Itt kell motiváló erővel belépnünk és az egyénre lebontva a segítséget megadnunk. Sokszor ez esetben nekünk is külön felkészülést jelent e feladatnak eleget tenni. Úgy érezzük, hogy e tehetséggondozást iskolánknak biztosítani kell minden hallgatónk számára, hogy önmaga lehetőségeinek legfelsőbb szintjét elérje, legyen átlag alatti, átlagos, vagy kiemelkedö képességü.

Jókai Anna Kossuth-díjas írónk útravalóként a következőt hagyta e tekintetben számunkra. „Az teszi jól, aki közeledésben oldódik és elfelejti a különállást.” (Jókai Anna)

\section{Felzárkóztatás és tehetséggondozás}

Szólni kell még a tehetségesek „képességgondozásáról”, vagyis meg kell tanítani őket élni a saját lehetőségeikkel. Együtt élni társaikkal és a felnőttekkel, és mindenekelött bíztatni őket, hinni bennük. Ez különösen azok esetében lehet fontos, akik családi helyzetüknél fogva hátrányosak és annak következtében nem képesek erre.

A tehetségek elkallódása legtöbbször nem képességük kifejletlensége miatt szokott bekövetkezni, hanem személyiségük ,gondozatlansága” miatt. Az oktatási intézmény legspeciálisabb és legfontosabb tehetséggondozási feladatát pszichológiai megközelítésben - ebben látjuk.

Az oktatás természetesen nem fejeződhet be azzal, hogy az oktató kimegy az elöadóteremböl. A törődés számtalan formában él tovább, amely speciális feladatokat jelent. Szükség van az érzelmi ráhangoltság megteremtésére is. Minden adott lehetőséggel élnünk kell a hallgatókkal való kommunikáció tekintetében. Adjunk át élményeket és tegyünk lehetővé élményszerü megnyilatkozásokat.

Az élet közeliségnek a duális és kooperatív képzési forma határozottan motiváló tényezője. A gyakorlati élettel való kapcsolat kialakítása, megteremtése különösen fontos szerepet kap, amikor a hallgatót egyoldalúan nagyon sok elméleti tudás éri.

A továbbiakban még néhány gondolatban kell szólnunk a család szerepéről, ami a nyugodt tanulás hátterét jelenti. A pénz uralkodó szerepe megnőtt, ezzel együtt a hajszolt életvitel is megjelent. Ezen életmód sok családnál nem tudja biztosítani a gyerekeknek azt a hátteret, amely a kiegyensúlyozott, nyugodt egyetemi tanulmányokhoz szükséges. Számos esetben ez párosul a stresszel, a kapkodással, a figyelemzavarral. Mindezek a mai rohanó világunk fogyasztói társadalmában rendkívül értékromboló hatással bírnak. Mindezeket tetézi az egyébként is halmozottan hátrányos családokból kikerülő egyetemi hallgatók problematikája.

A mindennapi élet során kialakult helyzetek is számos kihívás elé állítják a hallgatókat, amelyekkel akár tudatosan, akár tudatlanul kerülünk szembe. Gyakran kerülnek egyetemi tanulmányaik során is váratlan helyzetekbe, ezeket tudni kell kezelni. A hallgatóink nem csak különböznek egymástól, de különböző élethelyzetekben maguk is különbözően cselekednek. Találkozunk olyannal is, 
amikor a személyiség igényei nincsenek összhangban a képességükkel. Minden kérdésben döntő, hogy mi a felfogása a kötelességröl, milyen a lelkiismerete. Ez etikai kérdés. Az is nehezíti helyzetünket, hogy ilyen esetben nem a hallgató akar mérnök lenni, hanem a család egzisztenciális elvárásaként jelentkezik az igény. Ezt kezelni nagyon nehéz.

Minden szerephez elvárások kapcsolódnak. Egyes hallgatók olyan feladatokkal is találkoznak, amelyek végrehajtására nem tartják magukat alkalmasnak, amikor a feladat lényegesen megterhelőbb, mint amire számított. A felmerülő problémák esetén segítséget kell, hogy adjon az oktató, mindamellett, hogy a feladatokat mindenkinek magának kell megoldania. Nem szabad a menetközben keletkezett konfliktusokat figyelmen kívül hagyni, ezeken át kell segíteni az érintetteket.

\section{Köszönetnyilvánítás}

Jelen tanulmány a Szegedi Tudományegyetemen készült az Európai Unió támogatásával. Projekt azonosító: EFOP-3.4.3-16-2016-00014.

\section{Irodalomjegyzék}

Salamanca Statement on Principles Policy and Pactice in Special Needs Educations UNESCO (1994), <http://www.unesco.org/education/pdf/SALAMA_E.PDF> (2019.01.05.)

Overcoming Exclusion through inclusive Approaches in Education. A challange and a vision Conceptual Paper for the Education Sector, UNESCO (2001), <https://unesdoc.unesco.org/ark:/48223/pf0000134785> (2019.01.05.)

Lendvai E., Pappné Sziládi K., Vidács A.: (2018): A Szegedi Tudományegyetem oktatási és szolgáltatási teljesítményének innovatív fejlesztése a munkaerö-piaci és a nemzetközi verseny kihívására való felkészülés jegyében (EFOP-3.4.3-16-2016-00014), AP1 Hallgatói diplomaszerzést segítő szolgáltatások, AP1_MK lemorzsolódást csökkentő program kifejlesztése az MK-n az MTMI területeken. Speciális igényű hallgatók felmérése a Mérnöki Karon, 2018 - Széchenyi 2020 Európai Unió Európai Szociális alap - Befektetés a jövőbe.

Gál J., Panyor Á., Farkas F. (2019): Sajátos nevelési igényű hallgatók képzése a Mérnöki Karon, A Szegedi Tudományegyetem oktatási és szolgáltatási teljesítményének innovatív fejlesztése a munkaerö-piaci és a nemzetközi verseny kihívására való felkészülés jegyében (EFOP-3.4.3-162016-00014), AP1 Hallgatói diplomaszerzést segítő szolgáltatások, AP1_MK lemorzsolódást csökkentő program kifejlesztése az MK-n az MTMI területeken. Speciális igényü hallgatók felmérése a Mérnöki Karon, 2018 - Széchenyi 2020 Európai Unió Európai Szociális alap Befektetés a jövőbe.

Csíkszentmihályi Mihály (2010): Tehetséges gyerekek - Flow az iskolában. Nyitott Könyvmühely, Budapest. 